\title{
PENYARING UDARA BERBASISKAN ARDUINO UNO SEBAGAI SOLUSI UNTUK MEMPERBAIKI KUALITAS UDARA DI DALAM RUANGAN KELAS SDN 003 BINAAN TANJUNGPINANG
}

\author{
DENY NUSYIRWAN ${ }^{1)}$ \& AL FIKRI ${ }^{2)}$ \\ ${ }^{1,2)}$ Fakultas Teknik, Program Studi Teknik Elektro, \\ Universitas Maritim Raja Ali Haji (UMRAH) \\ Jl. Politeknik Senggarang, Tanjungpinang 29100 \\ Email: denynusyirwan@umrah.ac.id ${ }^{l)}$
}

\begin{abstract}
ABSTRAK
Dengan semakin bertambahnya jumlah penduduk telah di ikuti juga dengan pertambahan jumlah kendaraan dan bangunan, sehingga secara langsung mengurangi luas wilayah hijau pepohonan yang berfungsi sebagai penyaring udara kotor. Untuk menjaga udara tetap bersih dan segar, maka di beberapa lingkungan telah ditanam pepohonan, sedangkan untuk didalam ruangan menggunakan telah di pergunakan Air Conditioning yang menggunakan tenaga listrik cukup besar. Dari hasil observasi langsung bersama siswa, telah ditemukan sebuah masalah di sekolah yaitu udara kotor. Oleh sebab itu didalam penelitian ini di usulkan sebuah solusi sederhana berupa purwarupa alat penyaring udara kotor berbasis arduino untuk menghasilkan ruangan yang bersih dari udara kotor dan nyaman ditempati oleh siswa di SDN 003 Binaan, Tanjungpinang Kota. Perangkat lunak yang dipergunakan untuk perancangan purwarupa virtual pada penelitian ini menggunakan aplikasi Autodesk Inventor. Selanjutnya mempergunakan Mikrokontroler Arduino pada pembuatan purwarupa sederhana yang akan dipergunakan untuk mengetahui fungsi dapat bekerja benar dan mendapatkan evaluasi dari calon pengguna. Dari hasil pengujian kegunaan bersama calon pengguna, didapatkan bahwa hasil inovasi baik dan mudah dipergunakan di sekolah.
\end{abstract}

Kata Kunci : Udara, siswa, arduino, sekolah.

\begin{abstract}
The increasing number of residents has been followed by the increasing of vehicles and buildings, thus will reduce the area of green trees that function as dirty air filters directly. To keep the air clean and fresh, trees have been planted in several areas, and for the indoor purposes use Air Conditioning that consume quite large electricity. From the results of direct observation with students, a problem has been found in the school namely dirty air. Therefore in this study a simple solution is made in the form of prototype of an Arduino-based dirty air filter device to produce a room that is clean of dirty air and comfortably occupied by students in the 003 Binaan Elementary School, Tanjungpinang City. The software used for designing virtual prototypes in this study uses the Autodesk Inventor application. Furthermore, using the Arduino Microcontroller in making simple prototypes that will be used to find out the functions can work correctly and get evaluations from prospective users. From the results of testing the usefulness with prospective users, it was found that the results of innovation are good and easy to use at school.
\end{abstract}

Keyword: Air, Student, Arduino, School. 


\section{PENDAHULUAN}

Lingkungan sekolah merupakan lingkungan dimana para siswa melakukan kegiatan. Banyak kegiatan yang bisa dilakukan para siswa di sekolah, mulai dari aktivitas belajar, bermain, berolahraga, serta banyak kegiatan lainnya yang bisa dilakukan para siswa, oleh karena itu, kondisi badan siswa harus terbebas dari penyakit dan bugar. Untuk menjaga kesehatan para siswa diperlukan lingkungan belajar yang sehat dan bersih, ruangan yang bersih diperlukan untuk menjaga kesehatan para siswa agar mereka dapat terus mengikuti pelajaran di dalam kelas dengan baik, ruangan yang bersih juga bisa menjaga fokus para siswa agar bisa menyerap ilmu dengan baik.

Penelitian ini memanfaatkan design thinking dengan menggunakan pendekatan proses desain rekayasa yang berbasis kepada pengguna. Penelitian untuk mendapatkan solusi dengan awal pendekatan Double Diamand yang diperkenalkan oleh Design Council kerajaan inggris raya. Dimulai dengan etnografi di SDN 003 Binaan Tanjungpinang Kota, observasi dan wawancara dengan siswa, selanjutnya dilakukan tahapan brainstorming terhadap permasalahan yang ditemukan di sekolah, dan berdiskusi untuk menentukan permsalahan utama. Selanjutnya akan dilakukan brainstorming solusi untuk permasalahan utama, dan pengerucutan untuk mendapatkan solusi utama yang akan dilanjutkan dengan pembuatan purwarupa dan pengujian fungsi.

\section{Penelitian Terdahulu}

Penelitian dengan judul Studi Kinerja Ventilas Mekanik Insuflasi untuk Kualitas Udara Dalam Bangunan adalah sebuah penelitian yang menitik beratkan kepada prediksi perbahan udara didalam ruangan yang didasarkan kepada perancangan ruangan. Perancangan ruangan secara cermat akan dapat berpengaruh terhadap penggunaan energi didalam ruangan untuk menjaga udara didalam ruangan tetap bersih. Oleh sebab itu, dengan penelitian ini akan dilakukan uji coba melalui simulasi dengan perangkat lunak CONTAM untuk memprediksi arah pergerakan udara dan kontaminan didalam ruangan.[1]

Adapun pada penelitian yang berjudul Sistem Monitoring dan Notifikasi Kualitas Udara dalam Ruangan dengan Platform IoT, mempergunakan mikrokontroler wemos dan sensor MQ135 kemudian terhubung secara nirkabel untuk simpan di database dan ditampilkan melalui grafik. Apabila pengukuran telah mencapai batas tertentu maka sistem akan memberikan notifikasi kepada pengguna. Dengan hasil dari penelitian ini diharapkan kepada pengguna selalu memperhatikan udara yang bersih dan sehat didalam ruangan.[2]

Dengan semakin bertambahnya jumlah penduduk maka akan selalu diikuti oleh semakin pesatnya mobilisasi personal maupun umum yang mempergunakan sarana transportasi. Oleh sebab itu perlu diketahui mengenai tingkat polusi yang terjadi sebagai salah satu upaya untuk menghindari terjadinya pencemaran udara berlebihan di lingkungan perkotaan. Saat ini, pengukuran kualitas udara masih dilakukan pada satu titik tertentu, melalui penelitian dengan judul Purwarupa Sistem Pemantauan Kualitas Udara dan Cuaca berbasis Wireless Sensor Network, pengukuran dapat dilakukan pada beberapa titik secara bersamaan dengan mempergunakan sistem jaringan penginderaan tanpa kabel.[3]

\section{METODE KEGIATAN PENELITIAN}

Peranan penting bagi ilmuwan pada abad ke-21 adalah berperan serta dalam mendidik masyarakat tentang metode dan hasil proses ilmiah [4], oleh sebab itu diperlukan proses desain rekayasa untuk mampu menghasilkan inovasi berbasiskan teknologi yang semakin berkembang dan memiliki fungsi yang tepat dan mudah untuk digunakan. Jika di masa lalu desainer dievaluasi hanya berdasarkan pada keterampilan teknis mereka, di masa depan akan lebih banyak lagi kebutuhan untuk desainer yang bersedia bekerja dengan pendekatan yang lebih sistemik dan strategis dalam skala yang lebih besar [5]. Proses Desain Rekayasa adalah merupakan sebuah proses didalam mendesain dengan berpusat kepada pengguna. dimulai dengan etnografi hingga menghasilkan sebuah purwarupa yang merupakan sebuah konsep solusi yang sesuai dengan kebutuhan di masyarakat.

Proses ini memiliki 4 tahapan, pada tahapan awal dimulai dengan observasi secara luas di masyarakat untuk mendapatkan permasalahan-permasalahan, tahapan kedua adalah proses pengerucutan dengan melakukan pemilihan permasalahan utama, tahapan ketiga adalah mengembangkan ide-ide sebagai solusi terhadap permasalahan utama dan tahapan 
terahir adalah menetukan solusi utama untuk dapat dilanjutkan ke tahapan pembuatan purwarupa dan pengujian terhadap pengguna, sila lihat Gambar 1. Dalam tahapan pengujian terhadap pengguna akan terdapat proses iterasi untuk mendapatkan masukan untuk perbaikan inovasi nantinya.

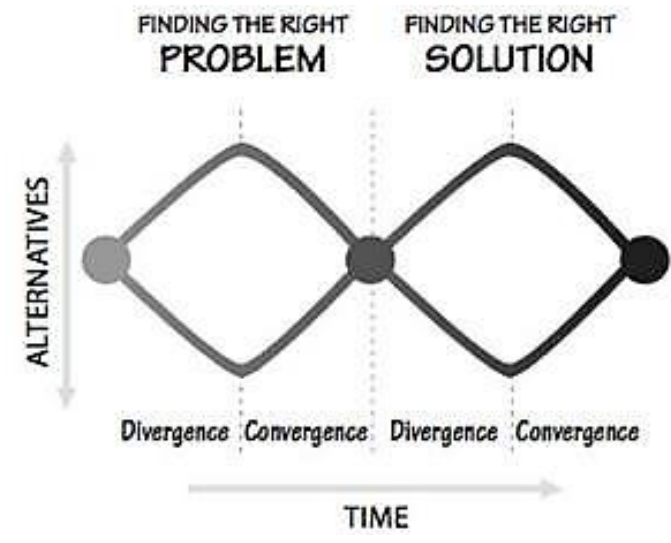

Gambar 1. Tahapan pada Proses Desain Rekayasa [6]

\section{Proses Etnografi}

Desain dan pemasaran adalah dua bagian penting dalam proses penelitian untuk melakukan pengembangan produk dan menghasilkan inovasi berbasis teknologi. Kedua bidang tersebut dapat saling melengkapi namun memiliki fokus yang berbeda. Peneliti untuk bidang desain sangat ingin tahu apa yang benar-benar dibutuhkan oleh calon pengguna dan bagaimana sebenarnya pengguna akan menggunakan produk yang sedang dipersiapkan. Sedangkan untuk peneliti di bidang pemasaran ingin tahu apa yang akan dibeli pengguna, termasuk mempelajari bagaimana pengguna membuat keputusan pembelian. Oleh sebab itu, dengan tujuan yang berbeda ini akan mengarahkan kedua kelompok tersebut untuk mengembangkan metode penyelidikan yang berbeda pula. Desainer cenderung menggunakan metode observasi kualitatif yang dengannya mereka dapat mempelajari orang secara mendalam, memahami bagaimana mereka melakukan kegiatan mereka dan faktor lingkungan yang ikut berperan [7]. Metode ini sangat memakan waktu, sehingga didalam penelitian ini hanya memeriksa sejumlah kecil orang. Adapun metode observasi yang dipergunakan adalah metode observasi peneliti sebagai peserta (observer as participant), yaitu kelompok yang sedang diteliti mengetahui tentang keberadaan peneliti, namun peneliti tidak ikut serta melakukan kegiatan dan aktifitas didalam kelompok yang sedang diteliti. Lokasi penelitian dilakukan di SDN 003 Binaan Tanjung pinang, Kepulauan Riau, lihat Gambar 2.

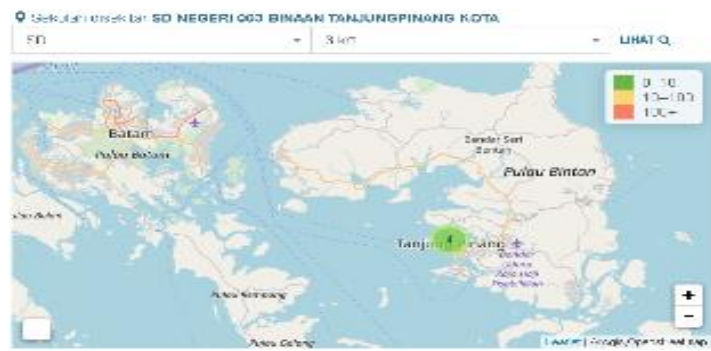

Gambar 2. Lokasi SDN 003 Binaan Tanjung pinang [8]

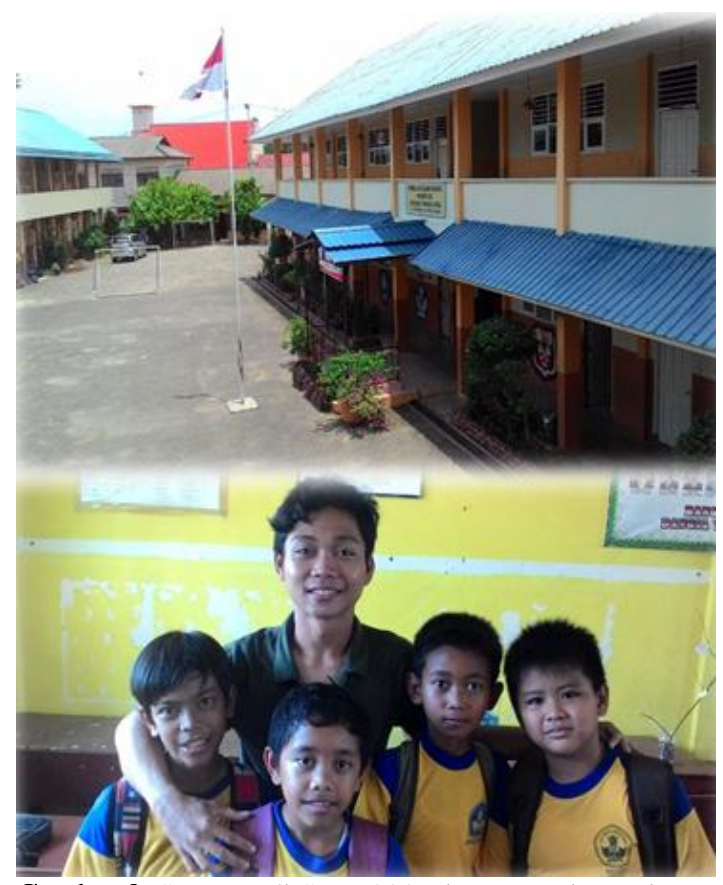

Gambar 3. Suasana di SDN 003 Binaan Tanjung pinang.

Langkah awal dari Proses Desain Rekayasa, yang merupakan aktivitas pegamatan atau observasi secara langsung ke masyarakat di suatu daerah untuk mendapatkan data yang akurat sehingga mampu menghasilkan sebuah solusi yang tepat. Pada Gambar 3 menampilkan keadaaan di SDN 003 Binaan Tanjung pinang untuk mendapatkan data-data yang di perlukan.

Metode etnografi yang diterapkan pada penelitian ini adalah peneliti sebagai peserta, dimana kelompok yang sedang diteliti mengetahui tentang keberadaan peneliti, namun peneliti tidak ikut serta melakukan kegiatan dan aktifitas didalam kelompok yang sedang diteliti [9]. Pada Gambar 4 memperlihatkan peneliti melakukan proses pengumpulan informasi di SDN 003 Binaan Tanjungpinang. 


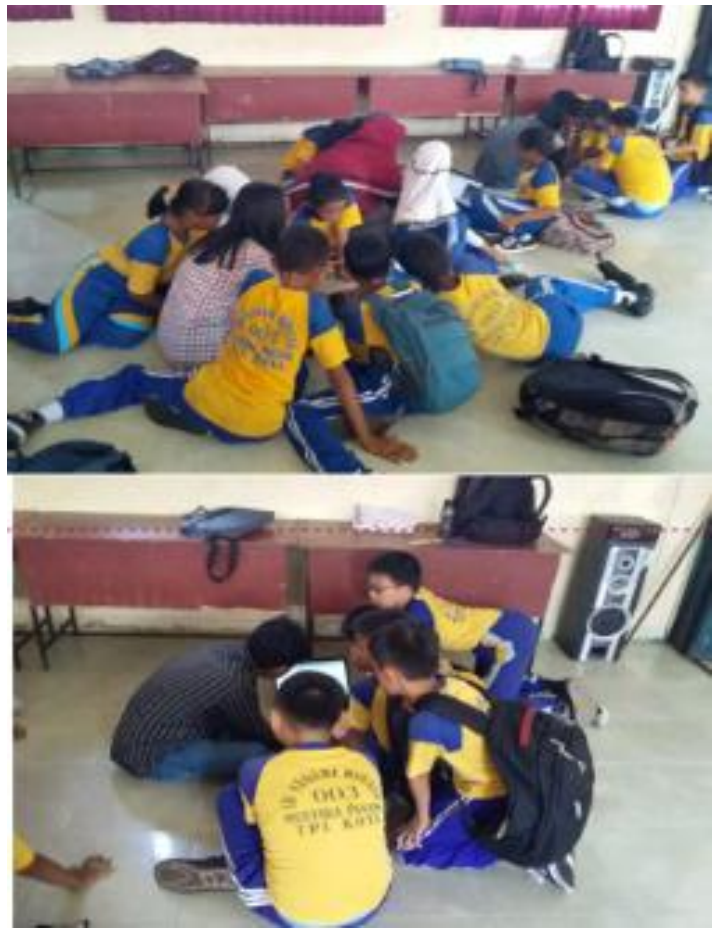

Gambar 4. Mengumpulkan informasi mengenai permasalahan yang terdapat di sekolah melalui siswa

\section{KARYA UTAMA}

Pada perancangan alat penyaring udara ini menggunakan papan arduino yang telah diberi sketch perintah untuk menjalankan alat. Setelah alat dihidupkan maka sensor debu akan membaca konsentrasi debu di dalam ruangan dan akan diproses oleh Arduino, jika terbaca kurang dari $1.0 \mathrm{pcs} / 0.01 \mathrm{cf}$ maka kipas akan mati, tetapi jika lebih dari itu maka kipas akan menyala. Hasil dari pembacaan dapat dilihat di serial monitor atau di LCD 16x2. Untuk menghidupkan kipas digunakan relay sebagai sakelar otomatis.Sila lihat Gambar 5.

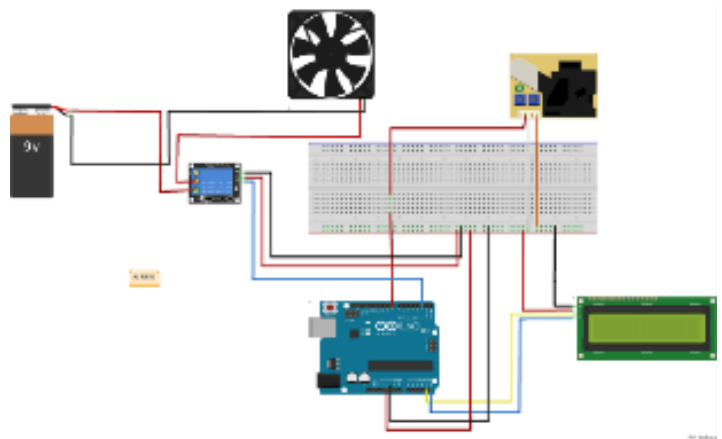

Gambar 5. Rangkaian elektronika Penyaring Udara

Adapun komponen yang diperlukan untuk pembuatan purwarupa dengan estimasi harga adalah sila lihat pada Tabel 1 .
Tabel 1. Estimasi anggaran (Bukalapak, diakses $28 \mathrm{Mei}$ 2019)

\begin{tabular}{|c|l|c|r|}
\hline No & \multicolumn{1}{|c|}{ Nama Komponen } & Jumlah & Harga (Rp) \\
\hline 1 & Lcd 16x2 + I2C & 1 & 29,400 \\
\hline 2 & Kipas DC 12 Volt & 1 & 7,000 \\
\hline 3 & Sensor Debu DSM501A & 1 & 123,500 \\
\hline 4 & Arduino Uno R3 & 1 & 89,000 \\
\hline 5 & Project Board & 1 & 23,000 \\
\hline 6 & Relay 1 channel & 1 & 7,000 \\
\hline 7 & Kabel Jumper & 2 set & 12,000 \\
\hline & Total & 6 & 290,900 \\
\hline
\end{tabular}

\section{Arduino UNO R3}

Arduino Uno R3 adalah merupakan sebuah mikrokontroller, dimana mikrokontroler tersebut akan memproses input yang diberikan melalui bahasa pemograman open source sehingga akan menghasilkan output. Cukup hubungkan Arduino dengan kabel USB ke PC atau Mac/Linux anda, jalankan software Arduino sudah bisa untuk memprogram chip ATmega328. Sila lihat Gambar 5.

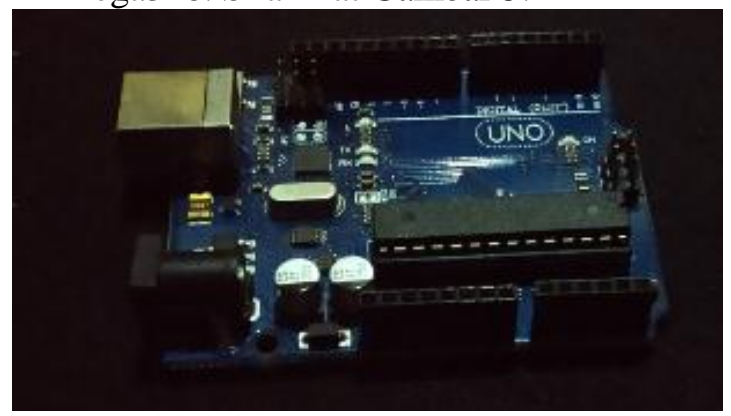

Gambar 5. Arduino Uno.

\section{Breadboard}

Breadboard adalah merupakan papan ujicoba rangkaian elektronika yang pada umumnya dipergunakan oleh pemula yang ingin mencoba. Papan dengan konstruksi berlubang sesuai untuk menancapkan komponen tanpa di hubungkan secara permananen. Komponen yang telah dipergunakan padas satu rangkaian akan dapat dipergunakan kembali tanpa mengalami kerusakan akibat perakitan sebalumnya., sila lihat Gambar 6.

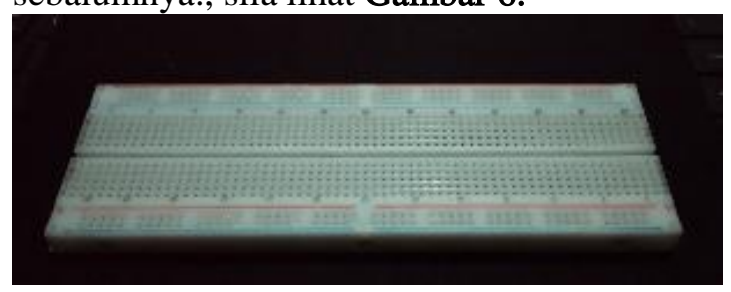

Gambar 6. BreadBoard

\section{Kabel jumper}

Pemula elektronika mempergunakan breadboard untuk menghindari terjadinya ke- 
sulitan ketika merangkai komponen elektronika. Sedangkan sebagai penghubung antara komponen akan dipergunakan kabel penghubung yang dikenal dengan jumper. Adapun bentuk dari kabe jumper adalah male-male, male female dan female-female, sila lihat Gambar 7.

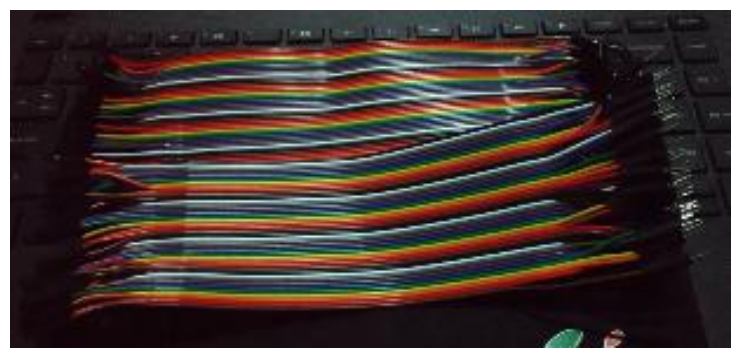

Gambar 7. Kabel Jumper.

\section{Liquid Cristal Display (LCD)}

Hasil proses dari mikrokontroler dapat ditampilkan dengan mempergunakan sebuah komponen yang terdiri dari kristal cair, dikenal dengan LCD (Liquid Crystal Display). Terdapat modul pada LCD untuk mengen-dalikan tampilan karakter, selain itu juga memori dan register serta pin. Sila lihat Gambar 8.

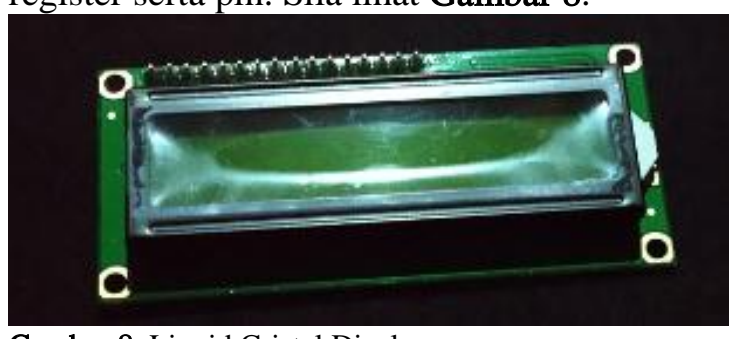

Gambar 8. Liquid Cristal Display

\section{I2C}

Penggunaan I2C secara teknis adalah untuk mempermudah didalam perangkaian komponen, dan mengurangi kesalahan didalam merangkai sehingga akan mengurangi bahaya terjadinya kerusakana pada LCD.. Sila lihat Gambar 9.

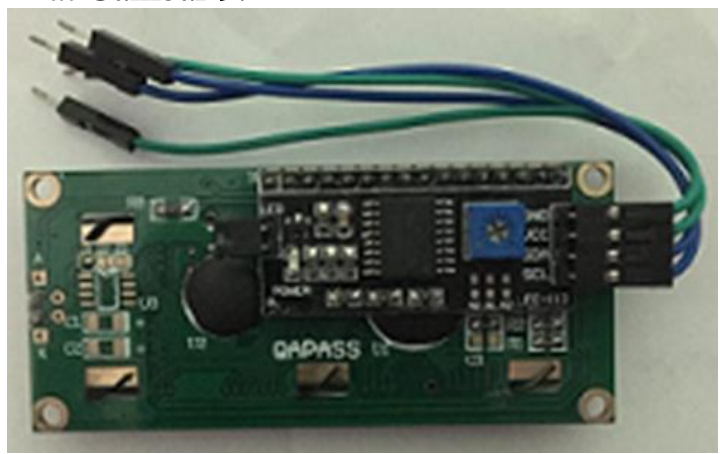

Gambar 9. I2C

\section{Sensor Debu}

Debu merupakan partikel yang memiliki ukuran diameter $<10 \mu \mathrm{m}$ atau yang sering disebut particulate matter (PM10). Sensor yang dapat digunakan untuk mengukur debu adalah DSM501A. Sensor DSM501A adalah sensor debu yang memanfaatkan hamburan cahaya atau disebut dengan sistem penginderaan optik. Sensor ini dilengkapi dengan LED dan fotodioda yang diatur secara diagonal. Sila lihat Gambar 10.

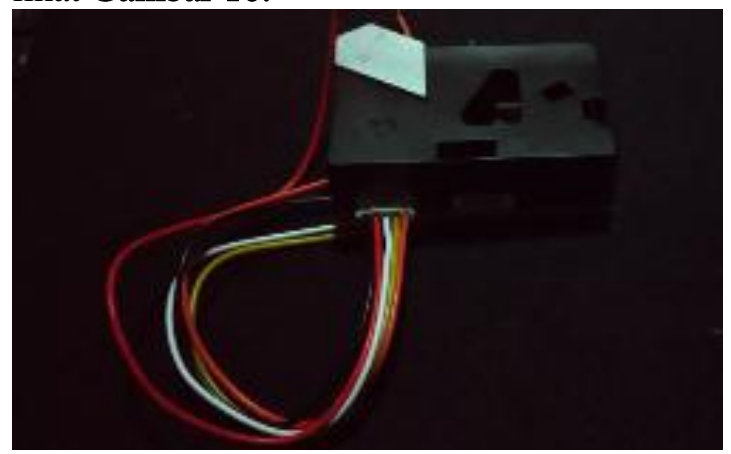

Gambar 10. Sensor Debu

\section{Relay 1 Channel}

Relay adalah sebuah komponen yang berfungsi sebagai pemutus dan penghubung yang akan bekerja secara otomatis berdasarkan aliran listrik. Kawat listrik yang dililitkan pada kumparan akan menghasilkan magnet sehingga akan menarik tuas saklar sehingga terhubung. Demikian pula apabila relay tidak mendapatkan listrik, maka tuas akan ditarik oleh pegas sehingga kemabli pada posisi semula, terbuka kembali.. Sila lihat Gambar 11.

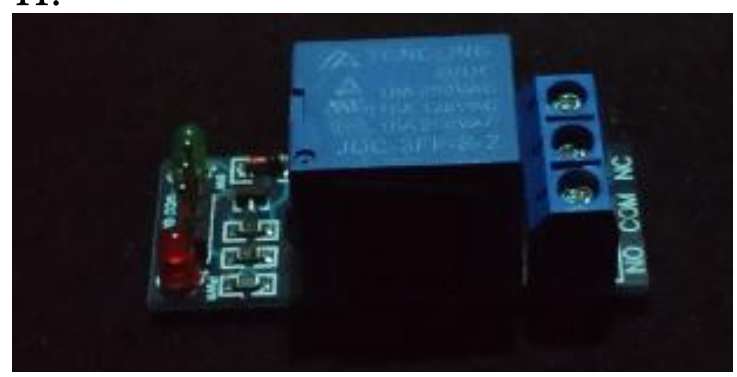

Gambar 11. Relay 1 channel

\section{Kipas $D C 12 v$}

Kipas DC akan dipergunakan untuk mengalirkan udara didalam ruangan menuju tempat air apabila konsentrasi debu sudah mencapai batas yang ditentukan, demikian juga sebaliknya. Sila lihat Gambar 12. 


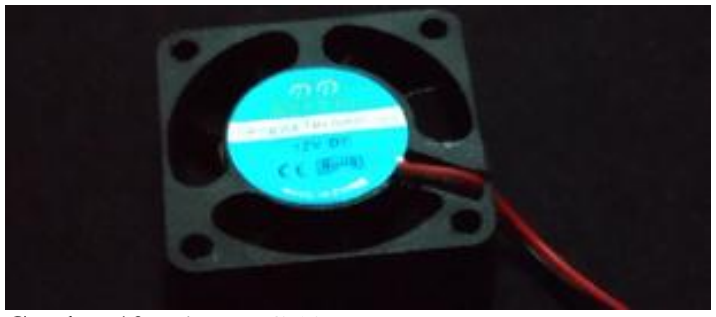

Gambar 12. Kipas DC 12v.

\section{ULASAN KARYA}

Tahapan selanjutnya adalah curahan gagasan permasalahan yang ditemukan di sekolah dari hasil observasi, dimana semua permasalahan yang ditemukan akan di dokumentasikan. Proses ini adalah merupakan tahapan yang penting, karena sangat diharapkan bahwa solusi yang akan dihasilkan adalah merupakan solusi yang dibutuhkan, bukan solusi yang diminta oleh calon pengguna.

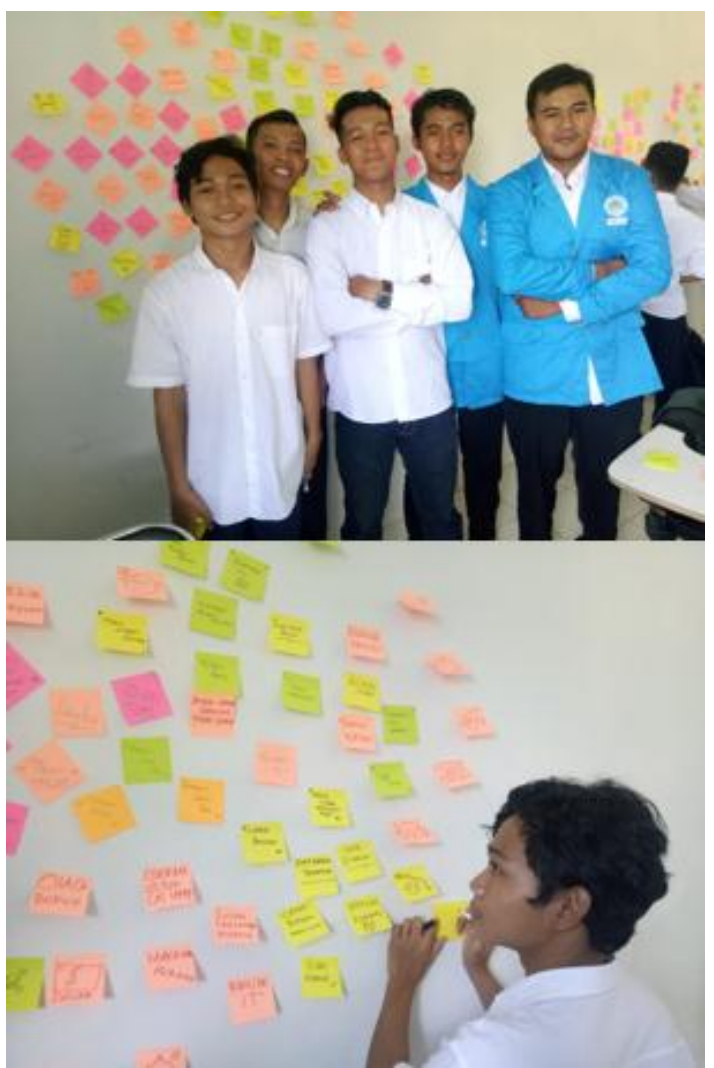

Gambar 13. Proses pengumpulan masalah

Pola penyampaian gagasan secara bebas akan sangat diperlukan untuk memotivasi peneliti untuk mampu berpikir inovatif dan kreatif. Curahan gagasan yang bersifat luas adalah merupakan pondasi bagi rekayasawan untuk mampu menghasilkan sebuah inovasi yang berbasiskan teknologi. Hal ini sering dipahami dengan $\mathrm{T}$ concept, dimaksudkan bahwa inovasi yang dihasilkan memiliki pe- ngaruh yang luas dan mendalam. Pada Gambar 13 dapat dilihat proses pengumpulan masalah-masalah yang sangat berkaitan dengan kejadian di sekolah selama melakukan observasi dan wawancara

Permasalahan utama adalah satu permasalahan yang akan dijadikan landasan untuk langkah penentuan solusi, dalam tahapan ini akan dilakukan proses pengerucutan masalah, dimulai dengan pengelompokan masalah dan selanjutnya di pilih satu masalah saja, lihat Gambar 14. Proses diskusi bersama sesama anggota kelompok dengan saling memberikan penjelasan terhadap masalah yang akan dijadikan masalah utama diperlukan untuk mendapatkan informasi-informasi yang belum dapat disampaikan pada tahapan sebelumnya. Adapun permasalahan utama dari penelitian ini adalah udara kotor didalam ruangan kelas.

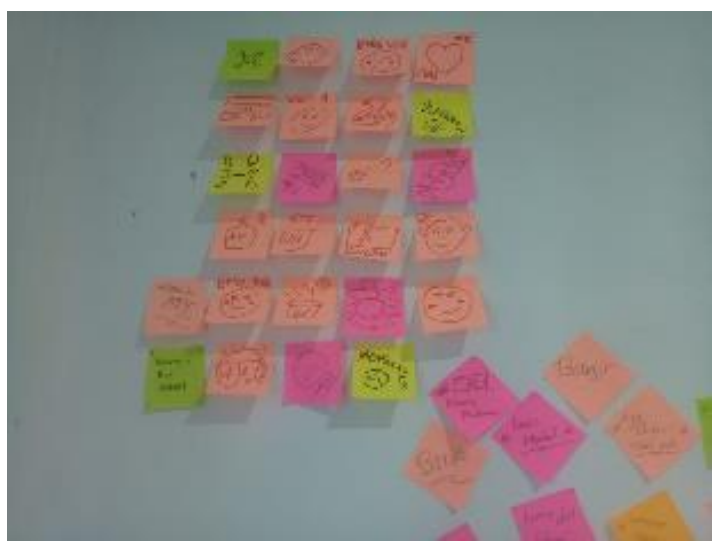

Gambar 14. Proses pengerucutan masalah untuk mendapatkan masalah utama

Tahapan curahan gagasan solusi dari masalah utama dilakukan setelah mendapatkan permasalahan utama. Dalam tahapan ini akan disampaikan beberapa konsep solusi bersama anggota peneliti lainnya. Dengan mempergunakan alat tulis yang dituangkan kedalam sketsa. Pada Gambar 14 menampilkan konsep solusi utama berupa perangkat penyaring udara. 


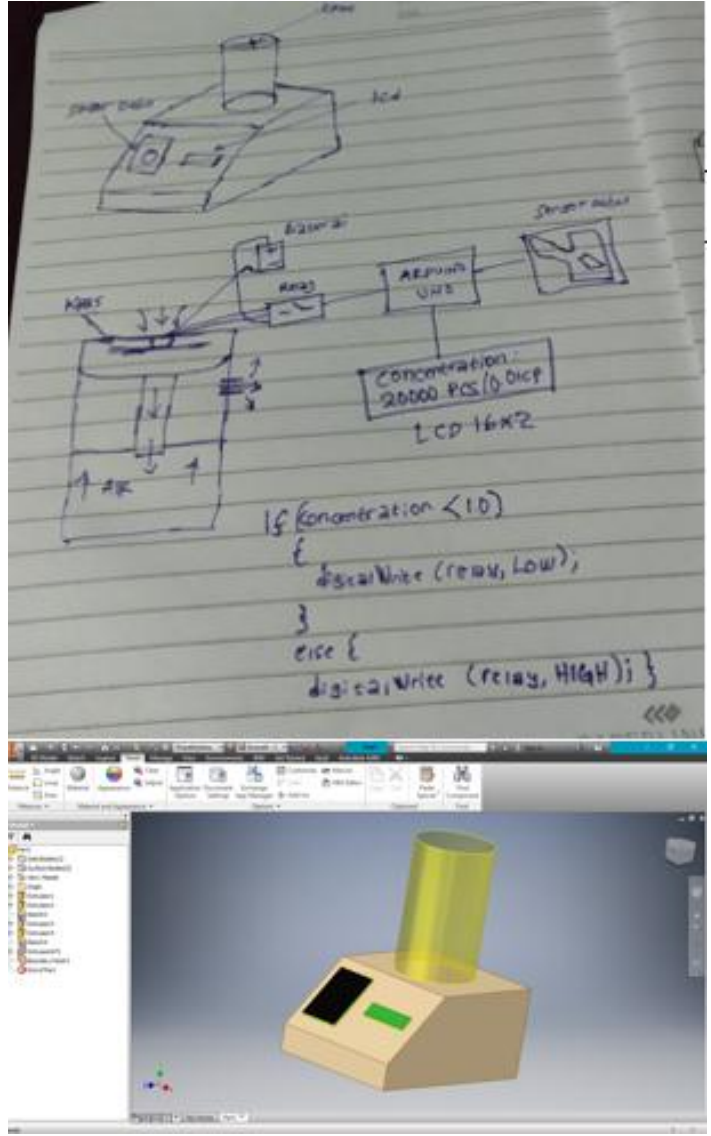

Gambar 14. Konsep solusi

\section{Purwarupa}

Tahapan yang sudah mulai memerlukan pembiayaan adalah tahapan pembuatan purwarupa. Oleh sebab itu pada Proses Desain Rekayasa ini, menekankan untuk mampu menghasilkan purwarupa sederhana yang ekonomis dan fleksible, dengan maksud bahwa perubahan rancangan dapat dilakukan dengan mudah dan tidak akan memerlukan pembiayaan yang besar. Purwarupa dalam tahapan ini lebih dikenal dengan istilah low resolution prototype [10]. Dapat dilihat pada Gambar 15 adalah sebuah purwarupa sederhana dari penyaring udara.

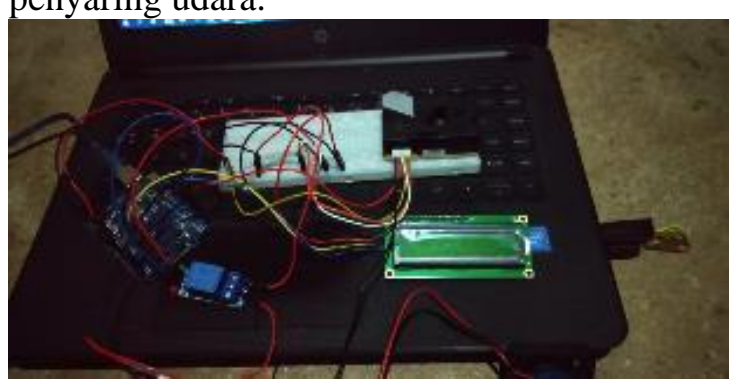

Gambar 15. Purwarupa Sederhana.

\section{Pengujian Kegunaan}

Pengujian kegunaan adalah proses evaluasi terhadap inovasi yang dirancang dengan berbasis pengguna. Pada tahapan ini pengguna akan berpartisipasi dan berinteraksi secara langsung dengan purwarupa sederhana yang dihasilkan dari proses sebelumnya. Pengguna akan diminta untuk melakukan tugas tertentu atau hanya menjelajahinya secara bebas, sementara perilaku pengguna diamati dan dicatat untuk mengidentifikasi kelemahan desain yang menyebabkan kesalahan atau kesulitan pengguna. Selama pengamatan ini, Setelah kelemahan desain telah diidentifikasi, rekomendasi desain diusulkan untuk meningkatkan kualitas ergonomis produk [11]

Pengalaman pengguna akan memperluas pandangan tentang interaksi produk dengan pengguna dari aspek emosional. Adapun motivasi dari proses pengalaman pengguna adalah untuk mengembangkan pengalaman dan emosi positif. Oleh karena itu, produk harus memenuhi kebutuhan psikologis dan motif pelanggan [12].

Pada Gambar 16 menampilkan pengujian kegunaan purwarupa.
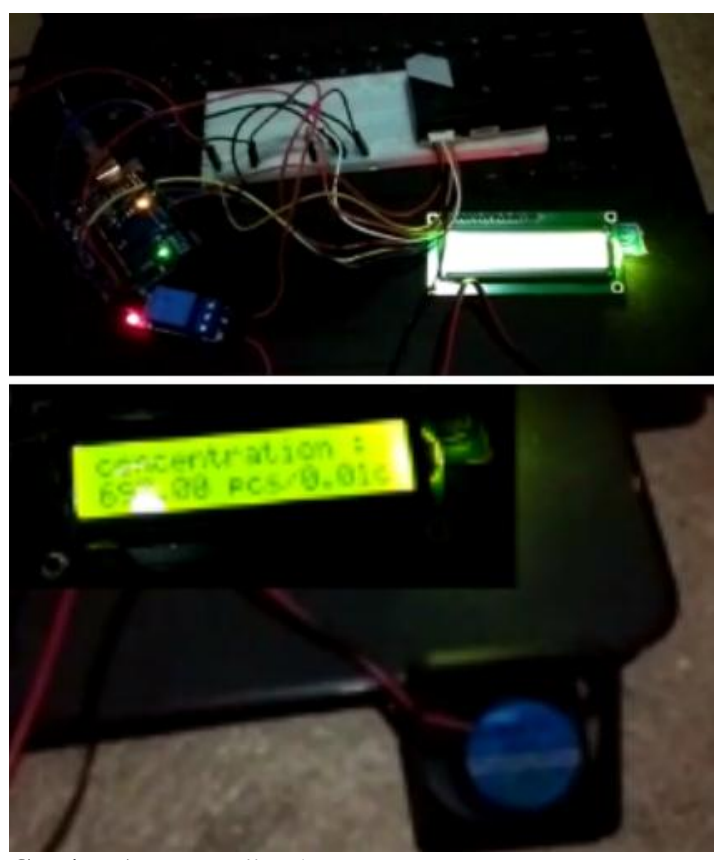

Gambar 16. Pengujian kegunaan

\section{Program pada Arduino}

Dibawah ini adalah program yang ditulis pada Arduino untuk dapat menghasilkan luaran sesuai yang di inginkan 


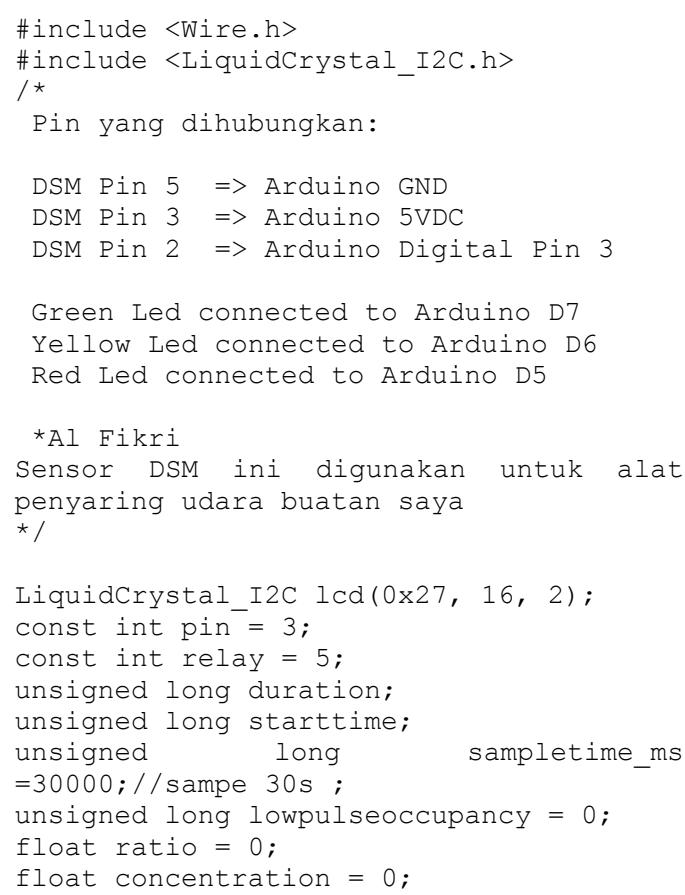

Gambar 17. Inisialisasi dan memasukan library komponen

Pada Gambar 17 menampilkan inisialisasi program, dimana pada purwarupa ini menggunakan LCD 16x2 lengkap dengan serial interface I2C, dan menggunakan sensor DSM untuk sebagai alat pendeteksi debu. Saat menggunakan serial interface maka kita harus sesuai kan alamat I2C agar pada saat di program tidak eror dan dapat berfungsi dengan baik. Menggunakan relay sebagai saklar on/off yang diletakin di pin 5 arduino.

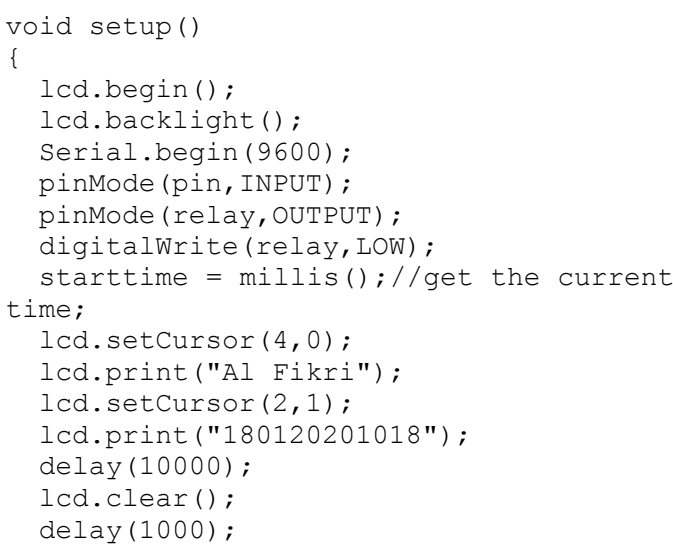

Gambar 18. Void setup untuk mengatur fungsi inisialisasi sebagai input/output.

Adapun pada Gambar 18 menampilkan fungsi pengaturan input dan output..Apabila menggunakan LCD 16x2 maka perlu memasukan inisialisasi nya di dalam void setup yaitu LCD.BEGIN dan LCD. BLACKLIGHT, menggunakan komunikasi serial monitor 9600 baud. Terdapat 1 input di pin arduino dan 1 output di pin arduino yaitu relay. Jarak set cursor di LCD berada di posisi 4,0 dan LCD menampilkan text monitor "al fikri" dan "180120201018".

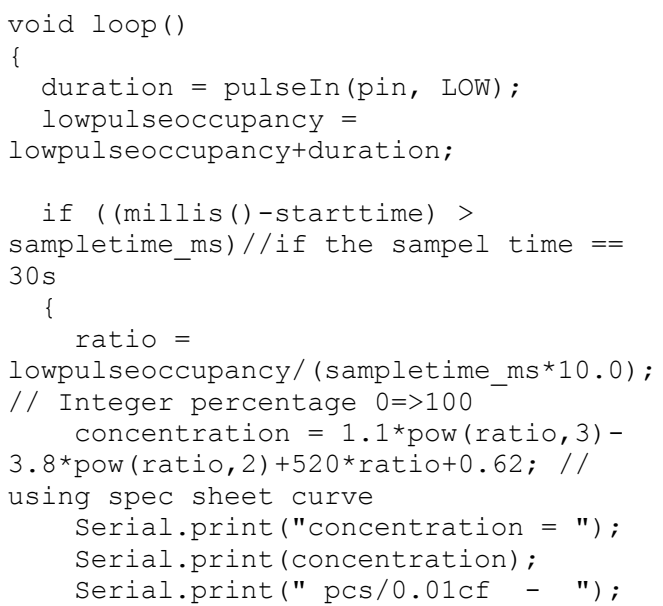

Gambar 19. Void loop / fungsi perulangan pada program.

Pada Gambar 19 menampilkan fungsi perulangan pad aprogram,. Fungsi perulangan pada prototype ini digunakan untuk mengulang pembacaan dari sensor yang digunakan. Dengan satuan millis dan ratio 0.62 sesuai dengan spesifikasi sensor yang digunakan, maka sensor akan bekerja dengan sendirinya dan mengulang terus menerus pembacaan sensor berdasarkan perintah dari program, LCD 16x2 akan menampilkan text monitor " concentration" dan "pcs/ $0.01 \mathrm{cf}$ - ".

\section{DAMPAK DAN MANFAAT KE- GIATAN}

Inovator yang berbasiskan teknologi sangat sadar bahwa kesuksesan hasil inovasi tidak hanya dilihat dari manfaat dari produk yang akan dihasilkan namun juga perlu memperhatikan faktor pengalaman pengguna., sehingga pengembangan inovasi teknologi tidak lagi hanya tentang mengimplementasikan fitur dan menguji kegunaannya, tetapi juga tentang mendesain produk yang menyenangkan dan mendukung kebutuhan dan nilai-nilai dasar manusia. Dengan demikian, pengalaman pengguna dalam tahapan Proses Desain Rekayasa harus menjadi perhatian 
utama pengembangan produk [13].

Tabel 2. Hasil pengujian kegunaan calon pengguna

\begin{tabular}{|c|c|c|c|c|}
\hline & $\begin{array}{ll}4 & 3 \\
\end{array}$ & 2 & \multirow[b]{2}{*}{ Keteraneasu } \\
\hline & & 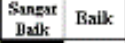 & Cukuq Kurane & \\
\hline 1 & $\begin{array}{l}\text { Purwarnos ini } \\
\text { muldah } \\
\text { ditgmakan? }\end{array}$ & & & 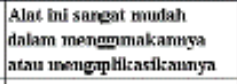 \\
\hline 2 & 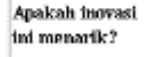 & & & $\begin{array}{l}\text { Noveurut saya alat ins } \\
\text { cangnt mpnartik }\end{array}$ \\
\hline 3 & 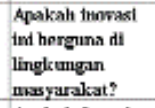 & & & 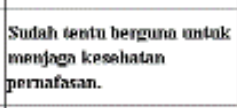 \\
\hline 4 & 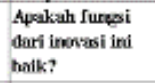 & & & 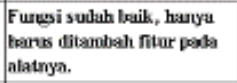 \\
\hline & $\begin{array}{l}\text { Apalkah sistem } \\
\text { dulast invwsi ini } \\
\text { sotah cotinnal? }\end{array}$ & & & Sulath uptinual. \\
\hline
\end{tabular}

Dari hasil pengujian didapatkan hasil yang baik. Inovasi berbasis teknologi ini akan mampu menjaga udara didalam ruangan tetap bersih dengan mengurangi debu didalam kelas sehingga akan mampu menjaga kesehatan siswa dan konsentrasi siswa didalam kelas. Selain hal tersebut, dengan penelitian ini telah menarik minta siswa terhadap teknologi untuk solusi terhadap permasalahan di lingkungan sekolah dan mulai menumbuhkan sifat technopreneuer.

\section{KESIMPULAN DAN SARAN \\ 1. Kesimpulan}

Permasalahan yang terjadi di sekolah pada umumnya dan di SD tempat penulis melakukan observasi khususnya ialah ruangan yang kotor dan kualitas udara si ruangan kelas yang tidak sehat. Maka daripada itu penulis membuat sebuah alat penyaring udara berbasis arduino untuk memperbaiki kualitas udara di ruangan kelas sehingga pelajar bisa lebih fokus dalam belajar dan terhindar dari gangguan pernafasan.

\section{Saran}

Penerapan alat ini bisa dilakukan pada ruangan selain ruangan kelas, karena alat ini dibuat untuk memperbaiki kualitas udara yang ada pada ruangan.

\section{DAFTAR PUSTAKA}

[1] Y., Kurniawan, Studi Kinerja Ventilas Mekanik Insuflasi untuk Kualitas Udara Dalam Bangunan, Jurnal Flywheel, Teknik Mesin Universitas Sultan Ageng Tirtayasa, Vol. II, No.1, pp 20-28, 2016

[2] J., M., S., Waworundeng, and 0., Lengkong, Sistem Monitoring dan
Notifikasi Kualitas Udara dalam Ruangan dengan Platform IoT, Cogito Smart Jurnal, Fakultas Ilmu Komputer Universitas Klabat, Vo. 4, No. 1, pp 94-103, 2018

[3] A. Sabiq, Nurmaya, T. Alfarisi, and Y. A. Pratama, ,Purwarupa Sistem Pemantauan Kualitas Udara dan Cuaca berbasis Wireless Sensor Network, Jurnal Sains dan Teknologi, Universitas Pendidikan Ganesha, Vol. 6, No. 2, 2017

[4] S. Kastner, and R. T. Knight, Bringing Kids into the Scientific Review Process. Neuron, Vol. 93, Edisi 1, pp 12-14, Elsevier Inc, 2017

[5] A. Irbīte, \& A. Strode, Design thinking models in design research and education, Proceedings of the International Scientific Conference. Vol. IV, pp 488-500, 2016

[6] Design Thinking - Double Diamond [Daring], Tersedia pada: https://www.linkedin.com/pulse/designthinking-double-diamond-patrick-leinen [ Diakses : 31 Mei 2019].

[7] Stanford University [Daring], Tersedia pada: http://web.stanford.edu [Diakses: 31 Mei 2019].

[8] Sekolah Kita [Daring], Tersedia pada: http://sekolah.data.kemdikbud.go.id/inde x.php/chome/profil/90AD19BD-31F5E011-B7F8-3B12490BB869 [Diakses: 31 Mei 2019].

[9] C. Wagner, B. Kawulich, \& M. Garner, Collecting Data Through Observation, Doing Social Research: A global context, McGraw Hill, 2012

[10] D. Nusyirwan, Engineering Design Process Engineering Student Centered Experience Learning (ESCEL) di Jurusan Teknik Elektro Universitas Maritim Raja Ali Haji (UMRAH). Jurnal Sustainable Vol. 06, No. 01, pp. 24-35, 2017

[11] J.M. C. Bastien, Usability testing: a review of some methodological and technical aspects of the method", International Journal of Medical Informatics, Vol. 79, Edisi 4, pp e18-e23, Elsevier Ireland Ltd, 2010. 
[12] C. von Saucken, F. Lachner dan U. Lindemann, Principles for User Experience What We Can Learn from Bad Examples, International Conference on Kansei Engineering \& Emotion Research, 2014
[13] G. I. Johnson, \& C. W. Clegg, \& S. J. Ravden, Towards Practical User Experience Evaluation Methods, Applied Ergonomics, Volume 20, Edisi 4, pp 255260, Elsevier Ltd, 1989 